\title{
Magnetite Oxide Nanomaterial Used for Lead Ions Removal from Industrial Wastewater
}

\author{
Oana Stoian ${ }^{1}$, Cristina Ileana Covaliu ${ }^{1}$ ** , Gigel Paraschiv ${ }^{1}$, Gina-Alina Catrina (Traistaru) ${ }^{2}$, Mihai Niță-Lazăr ${ }^{2}$, \\ Ecaterina Matei $^{1}$ (D), Sorin Ștefan Biriş ${ }^{1}$ and Paula Tudor ${ }^{1}$ \\ 1 University Politehnica of Bucharest, 313 Splaiul Independentei, 060042 Bucharest, Romania; \\ stoian_s_oana@yahoo.com (O.S.); paraschiv2005@yahoo.com (G.P.); ecaterinamatei@yahoo.com (E.M.); \\ biris.sorinstefan@gmail.com (S.Ș.B.); paulavoicu85@yahoo.com (P.T.) \\ 2 National Research and Development Institute for Industrial Ecology-ECOIND, \\ 71-73 Drumul Podu Dambovitei Str., 060652 Bucharest, Romania; traistaru_ginaalina@yahoo.com (G.-A.C.); \\ mihai.nita@incdecoind.ro (M.N.-L.) \\ * Correspondence: cristina_covaliu@yahoo.com; Tel.: +40-722-791-791
}

Citation: Stoian, O.; Covaliu, C.I.; Paraschiv, G.; Catrina (Traistaru),

G.-A.; Niță-Lazăr, M.; Matei, E.; Biriş, S.Ș.; Tudor, P. Magnetite Oxide Nanomaterial Used for Lead Ions Removal from Industrial Wastewater. Materials 2021, 14, 2831. https:// doi.org/10.3390/ma14112831

Academic Editor: Roberta G. Toro

Received: 14 April 2021

Accepted: 20 May 2021

Published: 25 May 2021

Publisher's Note: MDPI stays neutral with regard to jurisdictional claims in published maps and institutional affiliations.

Copyright: (c) 2021 by the authors. Licensee MDPI, Basel, Switzerland. This article is an open access article distributed under the terms and conditions of the Creative Commons Attribution (CC BY) license (https:/ / creativecommons.org/licenses/by/ $4.0 /)$.

\begin{abstract}
The aim of this article is to present a nonconventional method for the efficient removal of lead ions from industrial wastewater. For this purpose, magnetite nanomaterial was used, which was very easily separated from the wastewater at the end of the treatment due to its magnetic properties. Currently, nanotechnology is an efficient and inexpensive manner that is being researched for wastewater treatment. Additionally, iron oxide nanoparticles are widely used to remove heavy metal ions from water due to their special properties. The experimental results detailed in this article show the influence of $\mathrm{pH}$ and contact time on the process of adsorption of lead ions from wastewater. The magnetite nanomaterial had its maximum efficiency of speed when the wastewater had $\mathrm{pH} 6$. At a lower $\mathrm{pH}$, the highest treatment efficiency was over $85 \%$, and the required contact time has doubled. When the $\mathrm{pH}$ increases above 6, the precipitation process occurs. Langmuir and Freundlich models were used to describe the adsorption process.
\end{abstract}

Keywords: heavy metal; lead ions; adsorption; nanotechnology; wastewater treatment

\section{Introduction}

Various methods for removing lead have been used, including adsorption, coprecipitation [1], reverse osmosis [2], ion exchange [3], membrane filtration [4], etc. Among these, the most preferred method is adsorption, since it is simple, economical, and environmentally friendly.

Nanotechnology is used for environmental remediation because it can provide a potentially cheap and efficient way for wastewater treatment [5]. Magnetic nanoadsorbents such as spinel ferrites, maghemite, and hematite are strong adsorbents for the removal of pollutants from wastewater. The application of an external magnetic field will easily isolate them from the reaction media due to their magnetic properties. Additionally, the application of magnetic separation on the nanoadsorbents provides the invaluable benefit of the rapid recovery of toxic metals from wastewater [6]. Due to their easy separation from wastewater and low toxicity, iron oxide nanoparticles are commonly used for metal removal [7,8]; in addition, if the nanoparticles are composed of magnetite, they can be easily separated from the associated pollutants [9]. The literature shows that magnetite nanoparticles are of a wide variety and can be further modified to improve their properties. The literature shows numerous studies on the use of magnetic nanoadsorbents to remove specific heavy metals in their ionic states, such as chromium, nickel, arsenic, cobalt, lead, copper, and others [10-15]. Magnetite nanoparticles are a promising solution because they are hydrophilic, are super paramagnetic, and have a high surface area [16]. The efficient implementation of magnetic nanoadsorbents depends on their efficiency in the selective adsorption of the pollutants involved and their surface chemistry $[6,15]$. 
The potential process of lead ion adsorption on magnetite nanoparticles is shown in Figure 1. On the surface of the magnetite nanoparticles, certain surface groups are formed, namely $-\mathrm{FeOH}^{2+}$ and $-\mathrm{Fe}^{+}$, due to protonation and deprotonation. It is observed that -Fe-Omay easily bond with $\mathrm{Pb}^{2+}$.

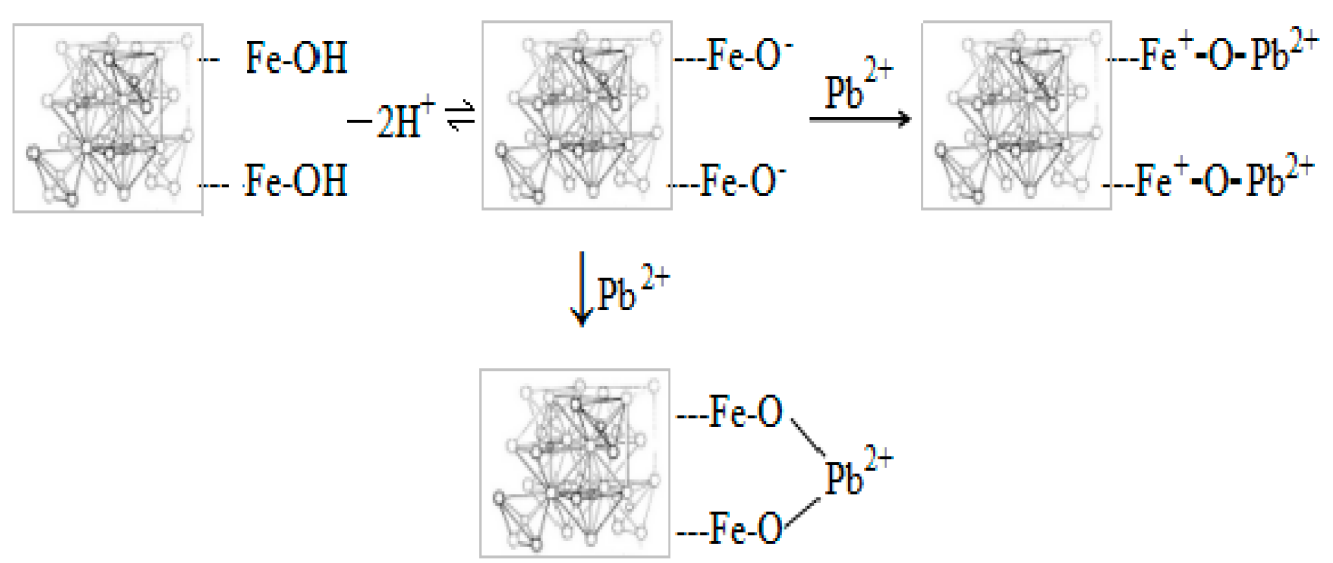

Figure 1. The adsorption mechanism of lead on magnetite nanoparticles [17].

The advantages of the adsorption method using magnetic nanomaterials, including magnetite, are their high efficiency of removal of heavy metal ions such as $\mathrm{Pb}$ (II), avoidance of secondary waste generation, production of no secondary pollutants, ability to treat large amounts of wastewater in a short time, good selectivity, and potential to be easily recycled and utilized on an industrial scale [18]. Due to their smaller size, magnetite nanomaterials have an increased surface area, thus improving adsorption capacities for lead ion removal.

Lead is one of the heavy metals that is associated with toxic poisoning even if it exists in low concentrations in wastewater. According to NTPA 001/2002, the maximum value of lead ions in wastewater must not exceed $0.20 \mathrm{mg} / \mathrm{L}$. In industrial wastewater, lead ions are found in concentrations of about $200-500 \mathrm{mg} / \mathrm{L}$; the concentrations are very high in relation to the values imposed by the legislation in force [19]. The main sources of lead ion pollution are effluents from battery processing, steel industries, fuels, paint pigment, photographic materials, automobiles, aeronautics, explosives manufacturing, or coating industries [20,21]. Accumulation of lead ions in the human body can lead to cancer, memory problems, brain damage, high blood pressure, kidney disease, premature birth, hearing loss, or low IQ in children [22-24].

In order to regenerate the magnetite nanoparticles, the researchers noticed that an acidic environment is needed $[25,26]$. Thus, a high regeneration efficiency using $0.1 \mathrm{M} \mathrm{H}^{+}$ was obtained, and the adsorption capacity of the reused magnetic nanoparticles remained almost constant over the next four cycles.

In order to remove lead ions from wastewater, the researchers used magnetite nanoparticles or composite nanomaterials that contain magnetite nanoparticles. Examples of the materials used in the lead ion adsorption process, which includes working conditions and treatment efficiencies, are recorded in Table 1.

In the present study, the adsorption process was applied in order to remove lead ions from wastewater. This article provides novel research through the following considerations: the utilization of magnetite nanoparticles with different characteristics [27] from other magnetite nanoparticles used in the adsorption process of lead ions from wastewater $[6,28,29]$, testing wastewater samples with different concentrations of lead ions $(0.70$, $1.00,1.20,1.45,1.64 \mathrm{mg} / \mathrm{L}$ ) from the scientific literature, and conducting experiments with two temperature values. 
Table 1. Materials used for lead removal from wastewater.

\begin{tabular}{|c|c|c|c|c|c|c|c|c|c|}
\hline Adsorbent & $\begin{array}{l}\text { Quantity of } \\
\text { Adsorbent } \\
\text { (g/L) }\end{array}$ & $\begin{array}{c}\text { Solution } \\
\text { Volume } \\
(\mathrm{mL})\end{array}$ & $\mathrm{pH}$ & $\begin{array}{l}\text { Contact } \\
\text { Time } \\
\text { (min) }\end{array}$ & $\begin{array}{l}\text { Speed } \\
\text { (rpm) }\end{array}$ & $\begin{array}{l}\text { Temp. } \\
\left({ }^{\circ} \mathrm{C}\right)\end{array}$ & $\begin{array}{c}\mathrm{C}_{\mathrm{i}} \\
(\mathrm{mg} / \mathrm{L})\end{array}$ & $\eta(\%)$ & Ref. \\
\hline $\mathrm{Fe}_{3} \mathrm{O}_{4}$ & 0.05 & 100 & $\begin{array}{l}4 \\
6 \\
9\end{array}$ & 30 & - & 25 & 50 & $\begin{array}{l}\approx 84.00 \\
\approx 85.00 \\
\approx 95.00\end{array}$ & {$[6]$} \\
\hline $\mathrm{Fe}_{3} \mathrm{O}_{4}$ & 1.00 & 50 & 5 & - & - & 25 & $\begin{array}{c}25 \\
50 \\
100\end{array}$ & $\begin{array}{l}91.00 \\
56.00 \\
31.00\end{array}$ & [28] \\
\hline $\mathrm{Fe}_{3} \mathrm{O}_{4}$ & 10.00 & 10 & 5.5 & 1440 & 200 & 25 & 220 & 100.00 & [29] \\
\hline Chitosan/magnetite & 0.10 & 100 & 6 & 120 & - & $\begin{array}{l}\text { Room } \\
\text { temp. }\end{array}$ & 70 & 90.47 & [30] \\
\hline $\begin{array}{l}\text { Magnetite }\left(\mathrm{Fe}_{3} \mathrm{O}_{4}\right) \text { nanospheres } \\
\mathrm{Fe}_{3} \mathrm{O}_{4} / \text { cyclodextrin polymer }\end{array}$ & $\begin{array}{c}1.00 \\
12.00\end{array}$ & $\begin{array}{l}50 \\
10\end{array}$ & $\begin{array}{c}5 \\
5.5\end{array}$ & 120 & 230 & $\begin{array}{l}25 \\
25\end{array}$ & $\begin{array}{c}10 \\
100\end{array}$ & $\begin{array}{c}>70.00 \\
99.50\end{array}$ & {$[31]$} \\
\hline $\begin{array}{c}\mathrm{PVP}-\mathrm{Fe}_{3} \mathrm{O}_{4} \\
15 \% \mathrm{Fe}_{3} \mathrm{O}_{4} / \mathrm{SiO}_{2}\end{array}$ & $\overline{-}$ & $\begin{array}{l}- \\
25\end{array}$ & $\begin{array}{l}6.5 \\
4.8\end{array}$ & $\begin{array}{l}90 \\
360\end{array}$ & $\begin{array}{c}200 \\
-\end{array}$ & $\begin{array}{l}- \\
\text { Room } \\
\text { temp. }\end{array}$ & $\begin{array}{c}1 \\
50\end{array}$ & $\begin{array}{l}100.00 \\
99.84\end{array}$ & [33] \\
\hline $\mathrm{Fe}_{3} \mathrm{O}_{4} @ \mathrm{SiO}_{2}-\mathrm{NH}_{2}$ core-shell & $\begin{array}{l}1.00 \\
1.00\end{array}$ & 50 & 5.2 & 960 & - & 25 & 148 & $\begin{array}{c}\approx 87.83 \\
45.00\end{array}$ & [34] \\
\hline L-cysteine functionalized $\mathrm{Fe}_{3} \mathrm{O}_{4}$ & $\begin{array}{l}2.00 \\
2.50\end{array}$ & 50 & 6 & 60 & 200 & 25 & 50 & $\begin{array}{l}99.00 \\
99.00\end{array}$ & [16] \\
\hline Natural goethite & 40.00 & 25 & 5 & - & - & 30 & 750 & 100.00 & [35] \\
\hline Peat moss & 0.24 & 100 & 6 & 180 & 125 & $23 \pm 1$ & 10 & 96.00 & [36] \\
\hline Waste beer yeast & 20.00 & - & 5 & 120 & 150 & - & $25-100$ & 96.34 & [37] \\
\hline Coal fly ash & 1.50 & 50 & - & 240 & - & - & 100 & 90.37 & [38] \\
\hline Sawdust waste & 2.00 & 50 & 6.5 & 240 & 200 & 30 & 103.6 & 88.60 & [39] \\
\hline Activated bamboo charcoal & 1.00 & 100 & 5 & 360 & 150 & 29 & 60 & 83.01 & [40] \\
\hline Banana peels & 40.00 & - & 5 & 20 & 100 & 25 & 50 & 85.30 & [41] \\
\hline Coconut shell & 1.00 & 50 & 4.5 & 180 & 180 & - & 10 & 99.00 & [42] \\
\hline Natural orange peel & 10.00 & 12 & 5 & 60 & - & $\begin{array}{l}\text { Room } \\
\text { temp. }\end{array}$ & 30 & 99.00 & [43] \\
\hline Ficus Religiosa leaves & 10.00 & 100 & 4 & 45 & 200 & 50 & 100 & 80.00 & [44] \\
\hline
\end{tabular}

\section{Materials and Methods}

In this study, the nanomaterial used to remove lead ions from synthetic wastewater was magnetite $\left(\mathrm{Fe}_{3} \mathrm{O}_{4}\right)$. This was obtained through the coprecipitation process. The magnetite particles applied in the process of adsorption of lead ions from wastewater were synthesized using a concentration of aqueous sodium hydroxide solution of $0.8 \mathrm{~mol} / \mathrm{L}$. The molar ratio of $\mathrm{Fe}^{2+}: \mathrm{Fe}^{3+}$ : PEG: PVP unit was set at 1: 2: 3: 4. Centrifugation was used to separate the precipitate, and then it was washed several times with water. Precursor calcination was performed at $410^{\circ} \mathrm{C}$ for a period of 2 hours to obtain $\mathrm{Fe}_{3} \mathrm{O}_{4}$ powder [27]. The reagents that were used to determine the concentration of lead ions (hydroxylammonium chloride, ammonia solution, and potassium cyanide) were purchased from Sigma-Aldrich, Burlington, MA, USA. The analysis of lead ion concentrations in synthetic wastewater was performed with the PhotoLab S12 photometer purchased from Wissenschaftlich-Technische Werkstätten GmbH (WTW), Weilheim, Germany.

All experiments were performed at room temperature and at $30^{\circ} \mathrm{C}$ with rotational speeds of 300 and $400 \mathrm{RPM}$ having different concentrations $(0.70 ; 1.00 ; 1.20 ; 1.45 ; 1.64 \mathrm{mg} / \mathrm{L})$, and the dose of adsorbent nanomaterial was $2.00 \mathrm{~g} / \mathrm{L}$. The $\mathrm{pH}$ values were set at 4 and 6 for each concentration using $0.1 \mathrm{M} \mathrm{HCl}$. The experimental results were obtained in accordance with ISO 8466-1 and DIN 38402 A51 (10-mm cell) with a measuring range between 0.010 and $5.00 \mathrm{mg} / \mathrm{L} \mathrm{Pb}$ (II).

The equilibrium adsorption amount $\left(\mathrm{q}_{\mathrm{e}}, \mathrm{mg} / \mathrm{g}\right)$ of $\mathrm{Pb}$ (II) ions was calculated using the following formula:

$$
\mathrm{q}_{\mathrm{e}}=\frac{\left(\mathrm{C}_{\mathrm{i}}-\mathrm{C}_{\mathrm{e}}\right) \times \mathrm{V}}{\mathrm{W}} .
$$

where $C_{i}$ is the initial concentration of $\mathrm{Pb}$ (II) ions (mg/L)

$\mathrm{C}_{\mathrm{e}}$ is the equilibrium concentration of $\mathrm{Pb}$ (II) ions $(\mathrm{mg} / \mathrm{L}$ )

$\mathrm{V}$ is the volume of the solution (L) 
$\mathrm{W}$ is the amount of the nanomaterial $(\mathrm{g})$.

Furthermore, the treatment efficiency $(\eta, \%)$ was also determined by the following equation:

$$
n=\frac{\mathrm{C}_{\mathrm{i}}-\mathrm{C}_{\mathrm{f}}}{\mathrm{C}_{\mathrm{i}}} \times 100
$$

where $\mathrm{C} i$ is the initial concentration of $\mathrm{Pb}(\mathrm{II})$ ions $(\mathrm{mg} / \mathrm{L})$

$\mathrm{Cf}$ is the final concentration of $\mathrm{Pb}$ (II) ions (mg/L).

In this article, two models of adsorption isotherms have been described in order to remove lead ions from wastewater, namely Langmuir and Freundlich.

The formula used to describe the Langmuir model is presented below:

$$
\mathrm{q}_{\mathrm{e}}=\frac{\mathrm{Q}^{0} \times \mathrm{K}_{\mathrm{L}} \times \mathrm{C}_{\mathrm{e}}}{1+\mathrm{K}_{\mathrm{L}} \times \mathrm{C}_{\mathrm{e}}}
$$

where $\mathrm{q}_{\mathrm{e}}$ is the quantity of $\mathrm{Pb}$ (II) adsorbed by magnetite at equilibrium (mg/g)

$\mathrm{Q}_{0}$ is the maximum monolayer coverage capacity $(\mathrm{mg} / \mathrm{g})$

$\mathrm{K}_{\mathrm{L}}$ is the Langmuir isotherm constant $(\mathrm{L} / \mathrm{mg})$

$\mathrm{C}_{\mathrm{e}}$ is the equilibrium concentration of adsorbate $(\mathrm{mg} / \mathrm{L})$.

The $\mathrm{R}_{\mathrm{L}}$ parameter was calculated using the following formula:

$$
\mathrm{R}_{\mathrm{L}}=\frac{1}{1+\left(1+\mathrm{K}_{\mathrm{L}} \times \mathrm{C}_{0}\right)}
$$

where $R_{L}$ is the value that indicates if the process is unfavorable $\left(R_{L}>1\right)$, linear $\left(R_{L}=1\right)$, favorable $\left(0<\mathrm{R}_{\mathrm{L}}<1\right)$, or irreversible $\left(\mathrm{R}_{\mathrm{L}}=0\right)$ [22]

$\mathrm{K}_{\mathrm{L}}$ is the Langmuir constant

$\mathrm{C}_{0}$ is the initial concentration [mg/L].

The Freundlich model is followed using the equation below:

$$
\mathrm{q}_{\mathrm{e}}=\mathrm{K}_{\mathrm{F}} \times \mathrm{C}_{\mathrm{e}}^{1 / \mathrm{n}}
$$

where $\mathrm{q}_{\mathrm{e}}$ is the quantity of metal adsorbed by magnetite at equilibrium $(\mathrm{mg} / \mathrm{g}$ )

$\mathrm{K}_{\mathrm{F}}$ is the Freundlich isotherm constant $(\mathrm{mg} / \mathrm{g}$ )

$\mathrm{C}_{\mathrm{e}}$ is the equilibrium concentration of adsorbate $(\mathrm{mg} / \mathrm{L})$

$\mathrm{n}$ is the adsorption intensity.

\section{Results}

\subsection{The $p H$ Effect}

The removal efficiency of lead ions from wastewater was performed at two $\mathrm{pH}$ values, 4 and 6. The results can be seen in Figure 2.

The experiments were done in triplicate. Thus, the error bars are presented in Figure 3 in the case of experiments performed on wastewater with $\mathrm{pH} 4$.

It can be seen that in the case of $\mathrm{pH}$ value 4 , the treatment efficiencies reach up to $84.40 \%$ in the case of the removal of a concentration of $1.00 \mathrm{mg} / \mathrm{L}$ of lead ions from the wastewater, while, at $\mathrm{pH}$ value $6,100 \%$ treatment efficiencies were obtained. It is also observed that with the increase of the initial concentration of lead ions, the required contact time increases more in the case of $\mathrm{pH} 4$ (from 180 to $420 \mathrm{~min}$ ) than in the case of $\mathrm{pH} 6$ (from 90 to $270 \mathrm{~min}$ ). Moreover, at $\mathrm{pH} \mathrm{6}$, the process is faster (up to $270 \mathrm{~min}$ ) than at $\mathrm{pH}$ 4 (up to $420 \mathrm{~min}$ ). The experiments performed at $\mathrm{pH}$ values greater than 6 do not show certainty that lead ions will be removed from the synthetic wastewater solution by the adsorption process. 


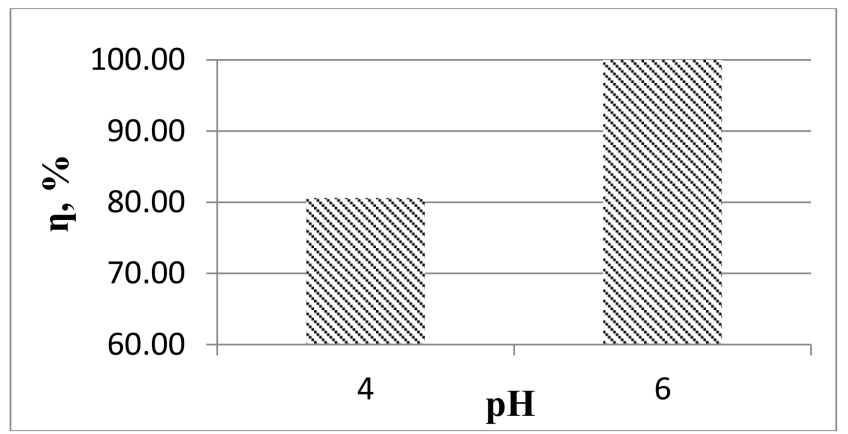

(a)

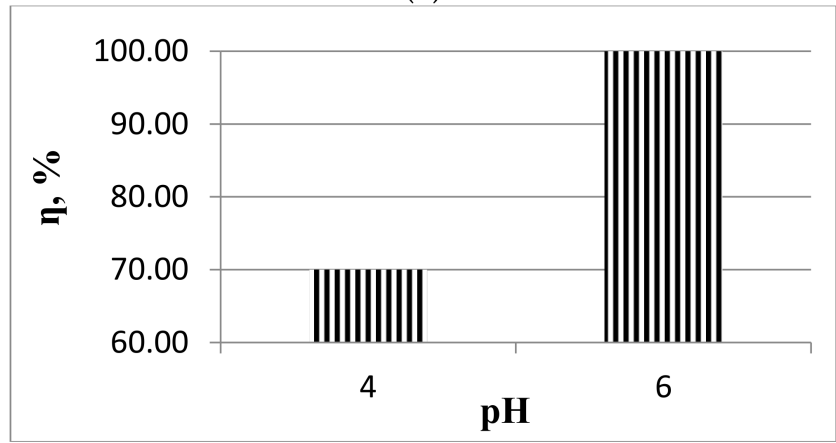

(c)

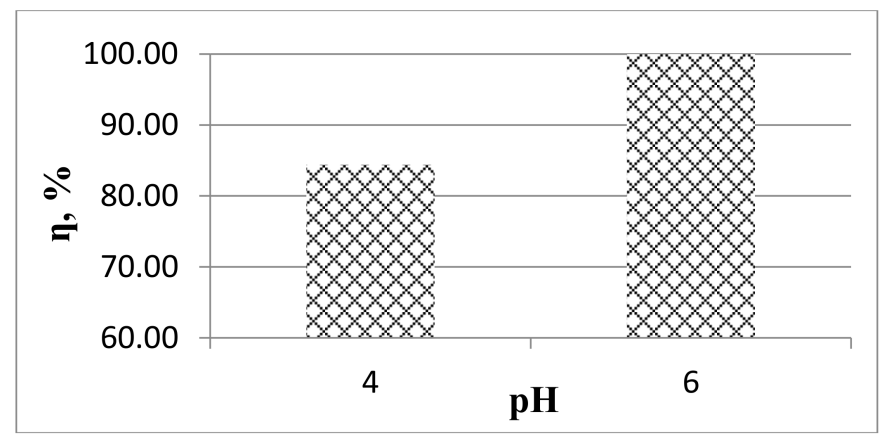

(b)

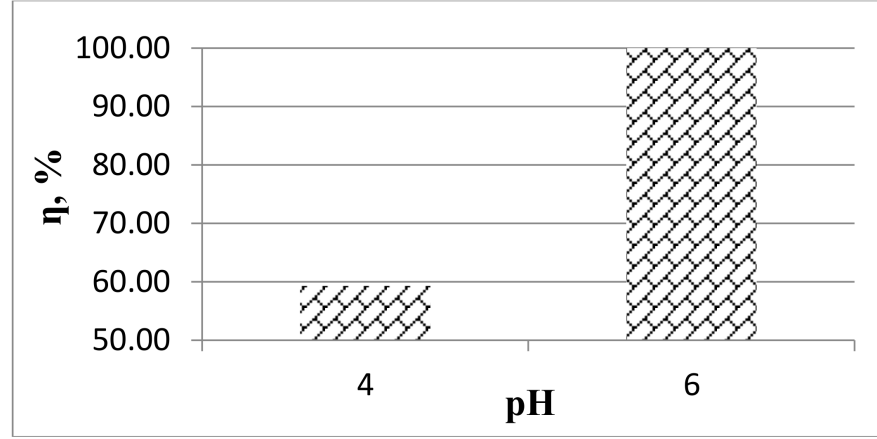

(d)

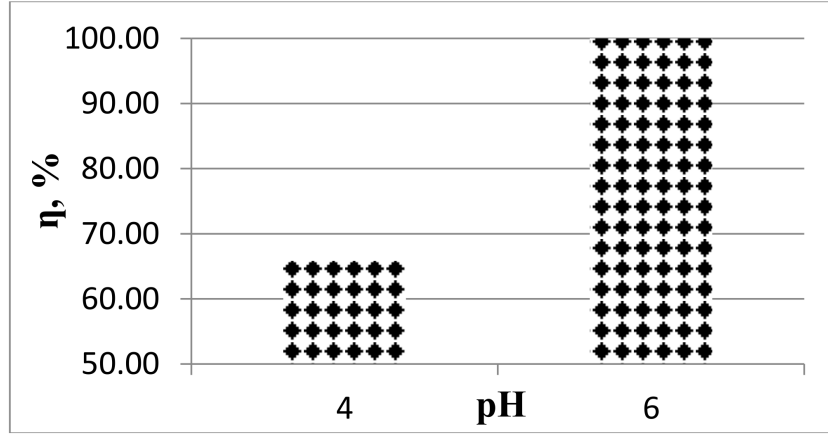

(e)

Figure 2. The $\mathrm{pH}$ effect on the removal process of $\mathrm{Pb}$ (II) ions (conditions: metal ion concentration 0.70 (a); 1.00 (b); 1.20 (c); $1.45(\mathbf{d}) ; 1.64(\mathbf{e}) \mathrm{mg} / \mathrm{L})$.

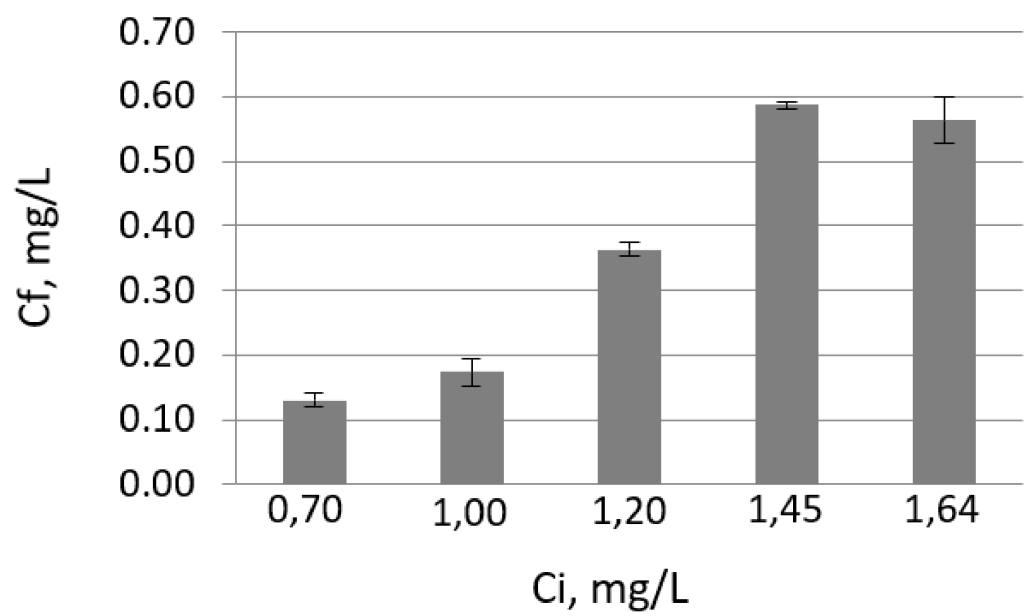

Figure 3. Error bars for experiments performed at $\mathrm{pH} 4$. 
In the case of the interaction of lead ions with the magnetite nanomaterial, the literature shows that in case of $\mathrm{pH}$ higher than $6.5 \mathrm{~Pb}(\mathrm{OH})_{2}$, it is the dominant species, and in case of $\mathrm{pH}$ lower than 6.5, we have $\mathrm{Pb}^{2+}$ and $\mathrm{Pb}(\mathrm{OH})^{+}$[45]. The reaction below demonstrates that the surface of the adsorbent nanomaterial can be subjected to protonation or deprotonation $[46,47]$ :

$$
\mathrm{H}_{2} \mathrm{O}+\mathrm{M}-\mathrm{O}^{-}<\frac{\mathrm{H}^{+}}{\mathrm{OH}^{-}}>\mathrm{M}-\mathrm{OH}<\frac{\mathrm{H}^{+}}{\mathrm{OH}^{-}}>\mathrm{M}-\mathrm{OH}_{2}^{+}
$$

Once the wastewater $\mathrm{pH}$ is basic, there will be a fairly high electrostatic attraction between the surface of the magnetite nanomaterial that is negatively charged and lead ions. When the $\mathrm{pH}$ of the wastewater decreases, the number of sites that are positively charged will increase, and the number of sites that are negatively charged will decrease. Thus, the adsorption of lead ions is not favored due to electrostatic repulsion. In an acidic environment, hydrogen ions that are present in excess will compete with lead ions for adsorption sites, and therefore the treatment efficiency is lower.

In water, magnetite nanoparticles present surface hydroxyl groups (Fe-OH). Depending on the $\mathrm{pH}$ of the wastewater, the protonation or deprotonation of the hydroxyl groups is observed. At $\mathrm{pH}<\mathrm{pH}_{\mathrm{pzc}}$ the surface of the nanoparticles is positively charged $\left(\mathrm{FeOH}_{2}{ }^{+}\right)$, and at $\mathrm{pH}>\mathrm{pH}_{\mathrm{pzc}}$ the surface of the nanoparticles is negatively charged $\left(\mathrm{FeO}^{-}\right)[28,48,49]$. As the $\mathrm{pH}$ of the wastewater increases from 4.0 to 6.0, the adsorption of lead ions increases due to the electrostatic attractions that occur between $\mathrm{Fe}-\mathrm{O}$ and $\mathrm{Pb}^{2+}$. The low adsorption of lead ions at $\mathrm{pH} 4$ is due to the competition for adsorption sites on the surface of available magnetite nanoparticles between $\mathrm{H}_{3} \mathrm{O}^{+}$and $\mathrm{Pb}^{2+}$. The inner surface of magnetite nanoparticles forms a complex that has a covalent bond between the lead ion and the surface oxide's oxygen.

\subsection{Contact Time Effect}

The effect of contact time on wastewater at $\mathrm{pH} 4$ and 6 was studied and can be seen in Figure 4.

From Figures 2 and 4, we can see that the concentration of lead ions decreases for a while, then increases. Thus, the treatment efficiency increases up to a certain percentage, then decreases. In the case of $\mathrm{pH}$ 6, the equilibrium concentration $(90 \mathrm{~min}$ for the initial concentration $0.70 \mathrm{mg} / \mathrm{L}, 150 \mathrm{~min}$ for the initial concentration $1.20 \mathrm{mg} / \mathrm{L}$ ) was reached in a shorter time than in the case of $\mathrm{pH} 4(180 \mathrm{~min}$ for the concentration $0.70 \mathrm{mg} / \mathrm{L}, 420 \mathrm{~min}$ for the initial concentration $1.20 \mathrm{mg} / \mathrm{L}$ ). In the first $60 \mathrm{~min}$ (at pH 4) and $30 \mathrm{~min}$ (at pH 6), the removal of lead ions from wastewater is faster due to the rapid occupation of the sites on the surface of the magnetite.

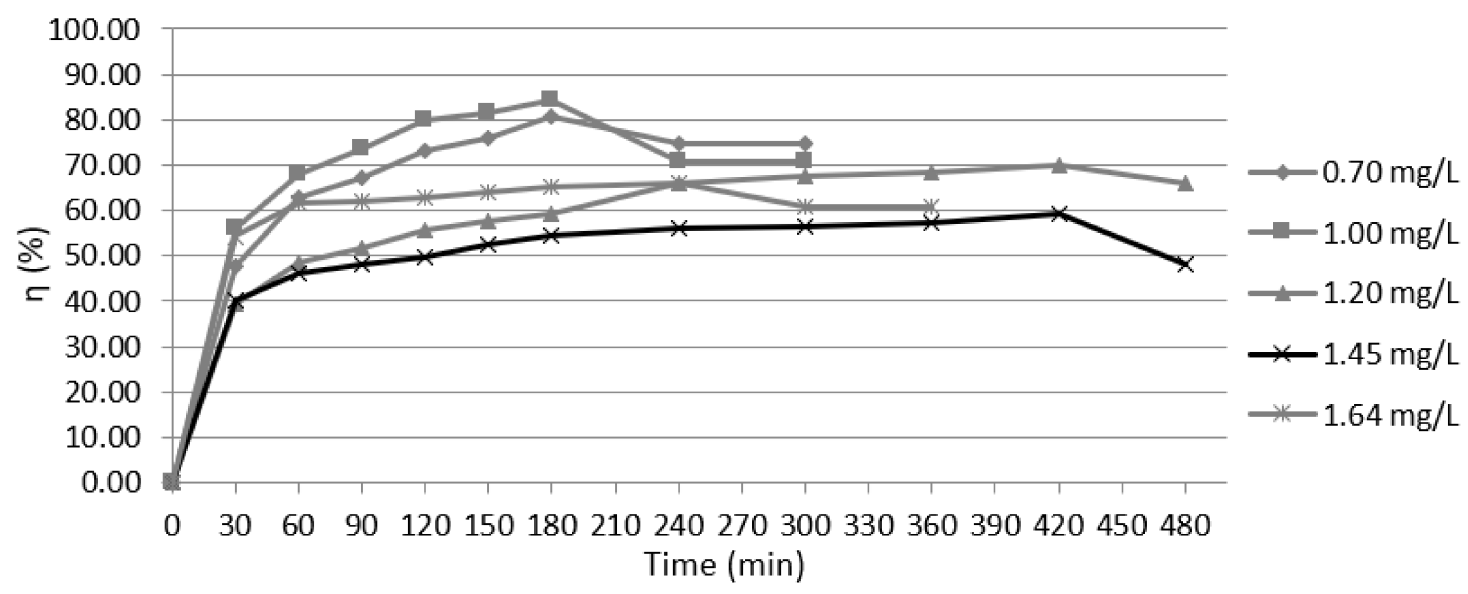

(a)

Figure 4. Cont. 


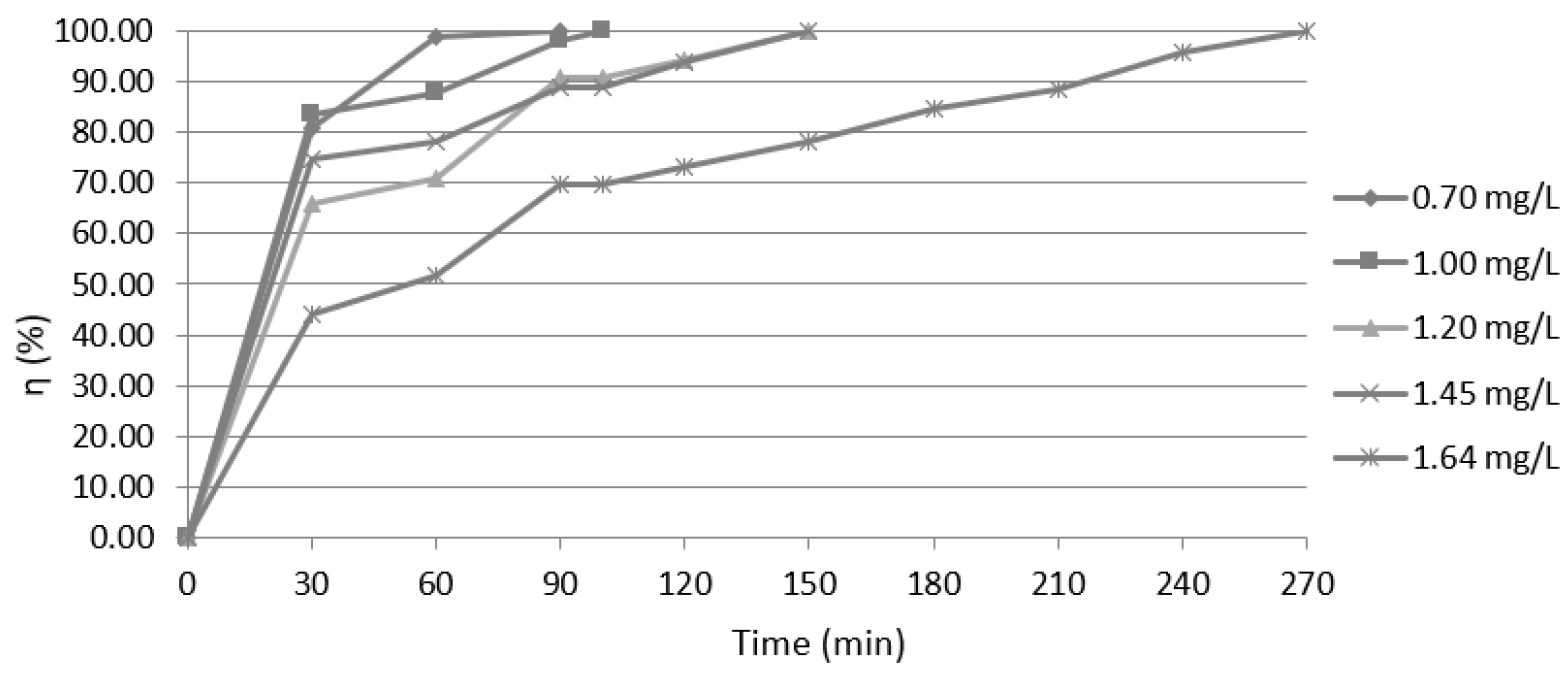

(b)

Figure 4. Efficiencies of wastewater treatment versus time at $\mathrm{pH} 4$ (a) and $\mathrm{pH} 6$ (b).

\subsection{The Impact of Temperature on the Adsorption Process}

To observe the effect of temperature on the adsorption process of lead ions on the magnetite nanomaterial, the temperature was increased to $30^{\circ} \mathrm{C}$, and the results are shown in Figure 5.

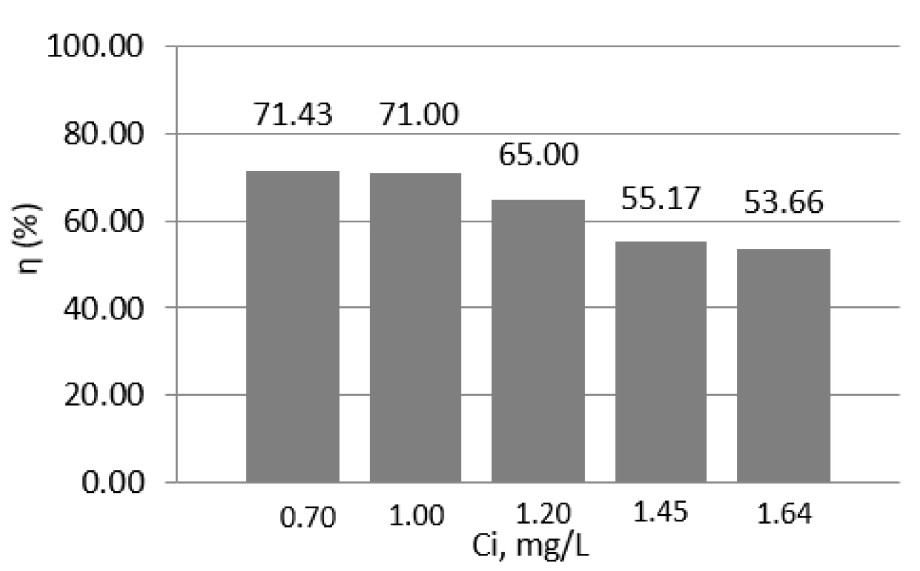

(a)

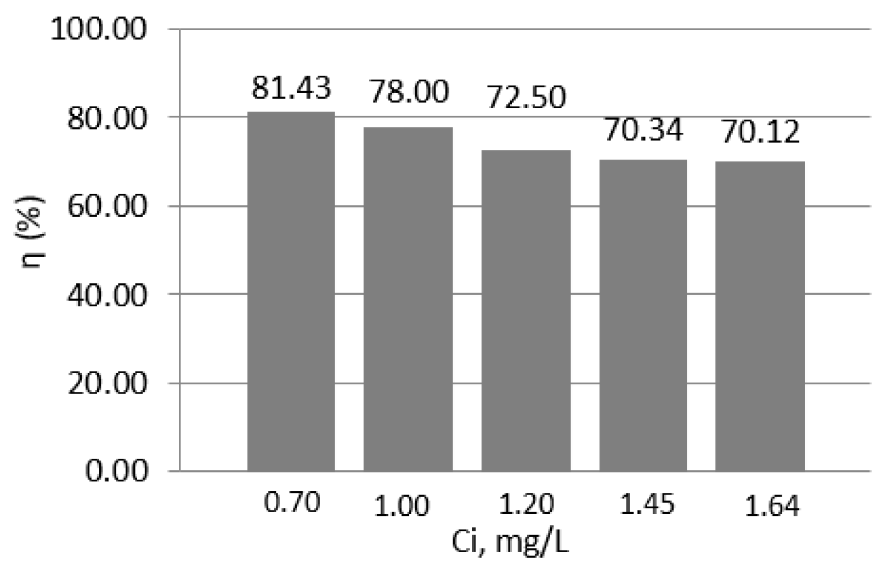

(b)

Figure 5. Efficiencies of wastewater treatment at $30^{\circ} \mathrm{C}$ versus initial concentrations at $\mathrm{pH} 4$ (a) and pH 6 (b).

In this case, increasing the temperature to $30^{\circ} \mathrm{C}$ leads to lower treatment efficiencies than in the case of the experiments performed at room temperature. In the case of $\mathrm{pH} 4$ and 6 , the difference between the two temperatures is between 4.14 and $13.4 \%$ and 18.57 and $29.88 \%$, respectively, depending on the initial concentrations of the pollutant.

\subsection{The Impact of Rotation Speed on the Adsorption Process}

The rotation speed was increased to 400 RPM to see if there was an improvement in the treatment efficiencies; the results can be found in Figure 6. 


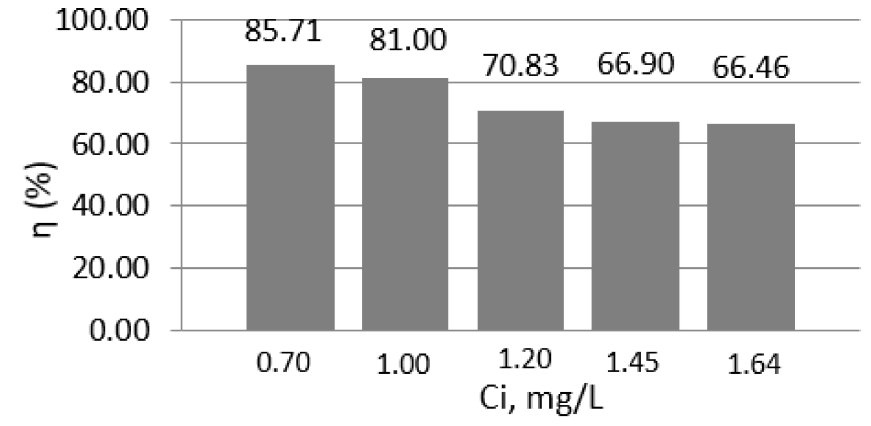

(a)

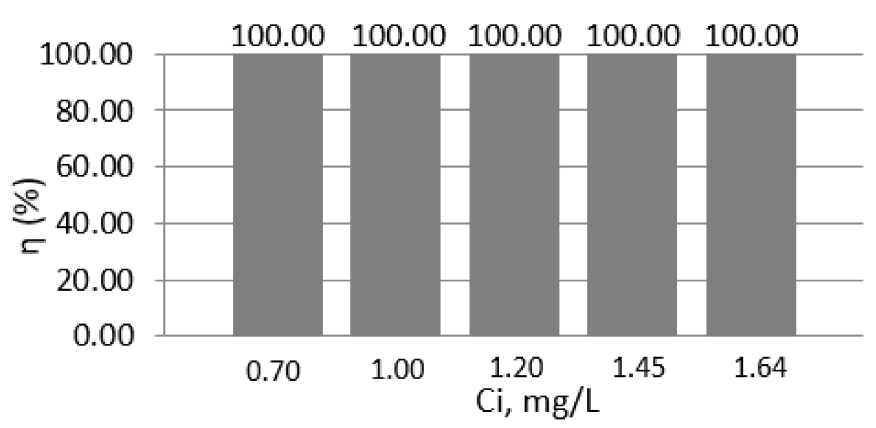

(b)

Figure 6. Efficiencies of wastewater treatment in the case of $400 \mathrm{RPM}$ versus initial concentrations at pH 4 (a) and pH 6 (b).

When the rotational speed was increased from 300 RPM to 400 RPM the results were clearer and increased slightly, the difference between the treatment efficiencies reaching up to a percentage of $7.59 \%$ depending on each initial concentration of lead ions. Apart from this aspect, the treatment time was shortened by up to $30 \mathrm{~min}$. In the case of $\mathrm{pH} 6$, the treatment efficiencies also reached $100 \%$.

\subsection{Adsorption Isotherms}

The experimental data were used for Langmuir and Freundlich models (Figures 7-9). Modeling of adsorption isotherms provides information about the adsorption process, the surface properties of the adsorbent nanomaterial, and its affinities. The constants of the Langmuir and Freundlich adsorption isotherms obtained from the processing of experimental data are presented in Table 2.

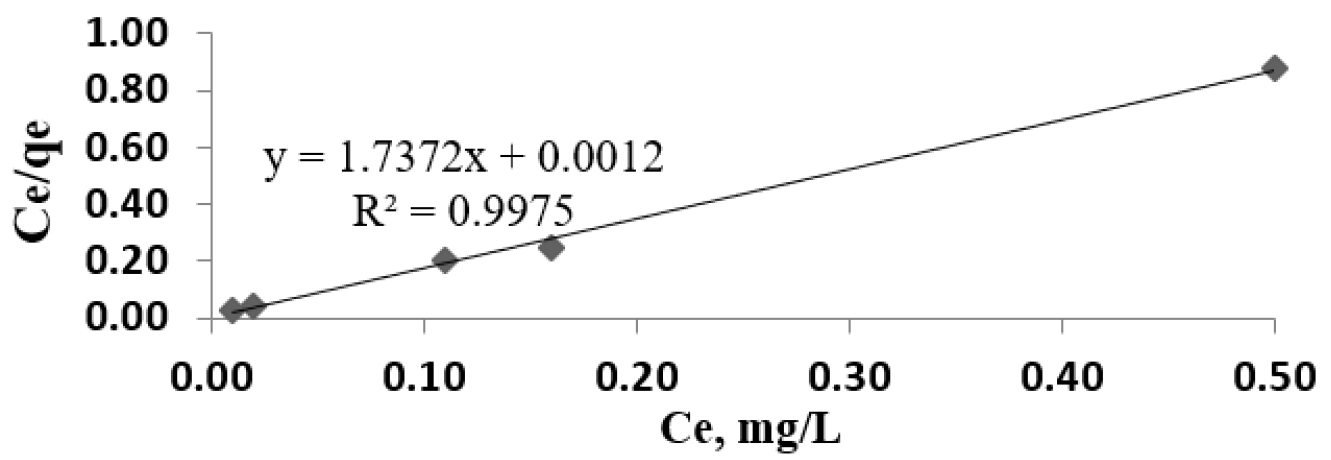

Figure 7. Experimental isotherm for different concentrations of lead ions $(0.70 ; 1.00 ; 1.20 ; 1.45$; $1.64 \mathrm{mg} / \mathrm{L})$.

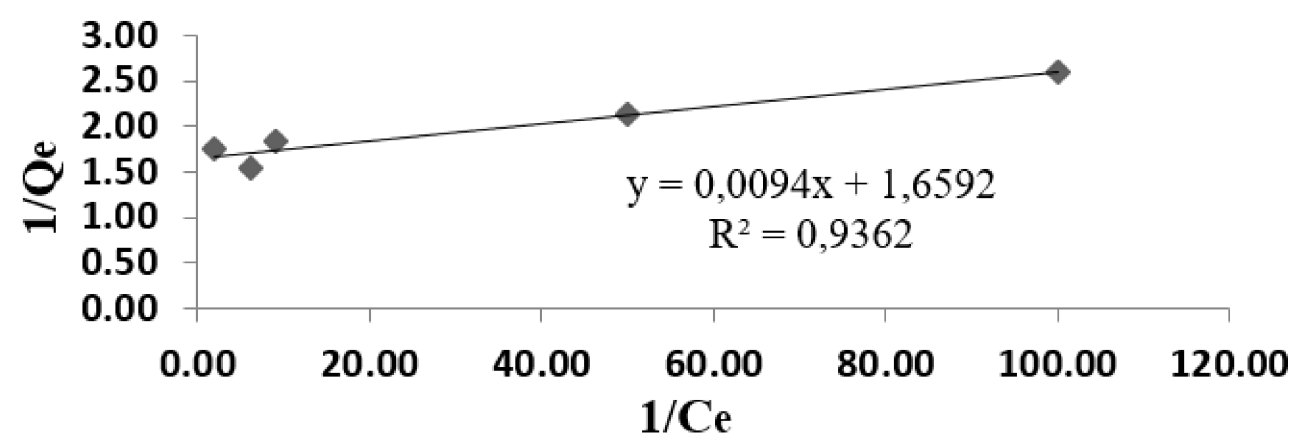

Figure 8. Langmuir model for the adsorption of lead ions from wastewater. 


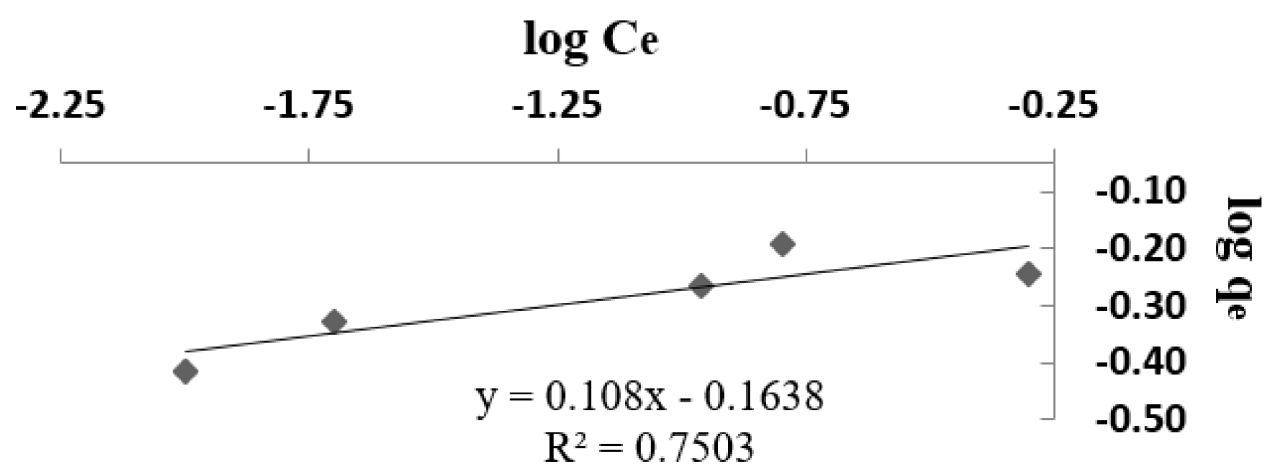

Figure 9. Freundlich model for the adsorption of lead ions from wastewater.

Table 2. Adsorption isotherm constants.

\begin{tabular}{|c|c|c|c|c|c|c|c|}
\hline Adsorbent & \multicolumn{3}{|c|}{ Langmuir Isotherm } & \multicolumn{4}{|c|}{ Freundlich Isotherm } \\
\hline \multirow{2}{*}{$\mathrm{Fe}_{3} \mathrm{O}_{4}$} & $\mathrm{~K}_{\mathrm{L}}(\mathrm{L} / \mathrm{mg})$ & $\mathrm{R}_{\mathrm{L}}$ & $\mathrm{R}^{2}$ & $1 / \mathrm{n}$ & $\mathrm{n}$ & $\mathrm{K}_{\mathrm{F}}(\mathrm{mg} / \mathrm{g})$ & $\mathrm{R}^{2}$ \\
\hline & 0.60 & 0.68 & 0.93 & 0.10 & 9.25 & 1.45 & 0.75 \\
\hline
\end{tabular}

Due to the fact that the $\mathrm{R}_{\mathrm{L}}$ value is between 0 and 1 , it is understood that the adsorption is favorable and that there is an efficient interaction between the adsorbent nanomaterial $\mathrm{Fe}_{3} \mathrm{O}_{4}$ and lead ions in accordance with the Langmuir model.

The Freundlich isotherm explains the monolayer and multilayer adsorption. The values $\mathrm{K}_{\mathrm{F}}$ and $\mathrm{n}$ can be determined using a linear equation resulting from plotting the curve $\log \mathrm{q}_{\mathrm{e}} / \log \mathrm{C}_{\mathrm{e}}$ (Figure 9). Thus, the value $1 / \mathrm{n}$ must be between 0 and 1 in order to apply the Freundlich model. In the present case, the value of $1 / \mathrm{n}$ is 0.10 , thus indicating that the adsorption process is favorable.

\section{Conclusions}

In the case of wastewater with $\mathrm{pH} 6$, the treatment efficiency reached $100 \%$ at all studied concentrations at room temperature. The highest treatment efficiency in the case of the removal lead ions from wastewater at $\mathrm{pH} 4$ was $85.71 \%$ at the initial concentration of $0.70 \mathrm{mg} / \mathrm{L}$ at room temperature when the rotational speed was set to $400 \mathrm{RPM}$. The required contact time is longer in the case of $\mathrm{pH} 4$ than in the case of $\mathrm{pH}$ 6. The minimum contact time at which the maximum treatment efficiency was reached was 60 minutes and 150 minutes in the case of wastewater with $\mathrm{pH} 6(100 \%)$ and $\mathrm{pH} 4(85.71 \%)$, respectively. There is also the phenomenon of desorption (reversible adsorption).

As the $\mathrm{pH}$ of the wastewater increases (up to $\mathrm{pH}$ 6), the adsorption of lead ions on the $\mathrm{Fe}_{3} \mathrm{O}_{4}$ surface is facilitated. On the other hand, if the $\mathrm{pH}$ rises above 6, the removal of lead ions can be achieved through the adsorption process, but precipitation can also occur due to the metallic hydrolysis of lead hydroxide.

Compared to the literature, in the case of the experiments presented in this article, the concentrations studied for lead ions were lower, but the importance of the $\mathrm{pH}$ of the wastewater was observed, and the treatment process was fast. The study of lower concentrations of lead ions in laboratory conditions demonstrates the maximum treatment efficiency, and the data can be reported on an industrial scale.

Author Contributions: Conceptualization, C.I.C., G.P. and O.S.; methodology, G.-A.C., P.T. and E.M.; supervision, S.S.B., M.N.-L. and P.T.; validation, C.I.C., E.M. and M.N.-L.; formal analysis, G.-A.C.; investigation, O.S.; writing — original draft preparation, O.S.; writing—review and editing, C.I.C.; visualization, G.P. and S.S.B. All authors have read and agreed to the published version of the manuscript.

Funding: This research was funded by Romanian Ministry of Education and Research, CCDIUEFISCDI, project number PN-III-P2-2.1-PTE-2019-0628, PTE 39/2020. 
Institutional Review Board Statement: Not applicable.

Informed Consent Statement: Not applicable.

Data Availability Statement: Data sharing is not applicable.

Acknowledgments: This work was supported by a grant from the Romanian Ministry of Education and Research, CCDI-UEFISCDI, project number PN-III-P2-2.1-PTE-2019-0628, PTE 39/2020.

Conflicts of Interest: The authors declare no conflict of interest.

\section{References}

1. Kameda, T.; Suzuki, Y.; Yoshioka, T. Removal of arsenic from an aqueous solution by coprecipitation with manganese oxide. J. Environ. Chem. Eng. 2014, 2, 2045-2049. [CrossRef]

2. Abejón, A.; Garea, A.; Irabien, A. Arsenic removal from drinking water by reverse osmosis: Minimization of costs and energy consumption. Sep. Purif. Technol. 2015, 144, 46-53. [CrossRef]

3. El-Din, A.F.T.; El-Khouly, M.E.; Elshehy, E.A.; Atia, A.A.; El-Said, W.A. Cellulose acetate assisted synthesis of worm-shaped mesopores of MgP ion-exchanger for cesium ions removal from seawater. Microporous Mesoporous Mater. 2018, 265, 211-218. [CrossRef]

4. Sunil, K.; Karunakaran, G.; Yadav, S.; Padaki, M.; Zadorozhnyy, V.; Pai, R.K. Al- $\mathrm{Ti}_{2} \mathrm{O}_{6}$ a mixed metal oxide based composite membrane: A unique membrane for removal of heavy metals. Chem. Eng. J. 2018, 348, 678-684. [CrossRef]

5. Patil, S.S.; Shedbalkar, U.U.; Truskewycz, A.; Chopade, B.A.; Ball, A.S. Nanoparticles for environmental clean-up: A review of potential risks and emerging solutions. Environ. Technol. Innov. 2016, 5, 10-21. [CrossRef]

6. Singh, R.; Bhateria, R. Experimental and modeling process optimization of lead adsorption on magnetite nanoparticles via isothermal, kinetics, and thermodynamic studies. ACS Omega 2020, 5, 10826-10837. [CrossRef]

7. Bagbi, Y.; Sarswat, A.; Mohan, D.; Pandey, A.; Solanki, P.R. Lead $\left(\mathrm{Pb}^{2+}\right)$ adsorption by monodispersed magnetite nanoparticles: Surface analysis and effects of solution chemistry. J. Environ. Chem. Eng. 2016, 4, 4237-4247. [CrossRef]

8. Palchoudhury, S.; Lead, J.R. A facile and cost-effective method for separation of oil-water mixtures using polymer-coated iron oxide nanoparticles. Environ. Sci. Technol. 2014, 48, 14558-14563. [CrossRef] [PubMed]

9. Hong, J.; Xie, J.; Mirshahghassemi, S.; Lead, J. Metal (Cd, Cr, Ni, Pb) removal from environmentally relevant waters using polyvinylpyrrolidone-coated magnetite nanoparticles. RSC Adv. 2020, 10, 3266. [CrossRef]

10. Badruddoza, A.Z.M.; Shawon, Z.B.Z.; Rahman, M.T.; Hao, K.W.; Hidajat, K.; Uddin, M.S. Ionically modified magnetic nanomaterials for arsenic and chromium removal from water. Chem. Eng. J. 2013, 225, 607-615. [CrossRef]

11. Lei, Y.; Chen, F.; Luo, Y.; Zhang, L. Three-dimensional magnetic graphene oxide foam $/ \mathrm{Fe}_{3} \mathrm{O}_{4}$ nanocomposite as an efficient absorbent for Cr (VI) removal. J. Mater. Sci. 2014, 49, 4236-4245. [CrossRef]

12. Ngomsik, A.F.; Bee, A.; Talbot, D.; Cote, G. Magnetic solid liquid extraction of Eu (III), La (III), Ni (II) and Co (II) with maghemite nanoparticles. Sep. Purif. Technol. 2012, 86, 1-8. [CrossRef]

13. Tan, L.; Xu, J.; Xue, X.; Lou, Z.; Zhu, J.; Baig, S.A.; Xu, X. Multifunctional nanocomposite $\mathrm{Fe}_{3} \mathrm{O}_{4} @ \mathrm{SiO}_{2}-\mathrm{mPD}_{\mathrm{SP}}$ for selective removal of $\mathrm{Pb}(\mathrm{II})$ and $\mathrm{Cr}(\mathrm{VI})$ from aqueous solutions. RSC Adv. 2014, 4, 45920-45929. [CrossRef]

14. Tu, Y.J.; You, C.F.; Chang, C.K.; Wang, S.L.; Chan, T.S. Arsenate adsorption from water using a novel fabricated copper ferrite. Chem. Eng. J. 2012, 440-448. [CrossRef]

15. Abbas, H.; Manasrah, A.D.; Abidi Saad, A.; Sebakhy, K.O.; Bouhadda, Y. Adsorption of Algerian asphaltenes onto synthesized maghemite iron oxide nanoparticles. Pet. Chem. 2021, 61, 67-75. [CrossRef]

16. Bagbi, Y.; Sarswat, A.; Mohan, D.; Pandey, A.; Solanki, P.R. Lead and chromium adsorption from water using L-cysteine functionalized magnetite $\left(\mathrm{Fe}_{3} \mathrm{O}_{4}\right)$ nanoparticles. Sci. Rep. 2017, 7, 7672. [CrossRef] [PubMed]

17. Zhang, J.; Lin, S.; Han, M.; Su, Q.; Xia, L.; Hui, Z. Adsorption properties of magnetic magnetite nanoparticle for coexistent Cr (VI) and $\mathrm{Cu}$ (II) in mixed solution. Water 2020, 12, 446. [CrossRef]

18. Khayat Sarkar, Z.; Khayat Sarkar, F. Selective removal of lead (II) ion from wastewater using superparamagnetic monodispersed iron oxide $\left(\mathrm{Fe}_{3} \mathrm{O}_{4}\right)$ nanoparticles as an effective adsorbent. Int. J. Nanosci. Nanotechnol. 2013, 9, 109-114.

19. Arbabi, M.; Hemati, S.; Amiri, M. Removal of lead ions from industrial wastewater: A review of Removal methods. Int. J. Epidemiol. Res. 2015, 2, 105-109.

20. Jalali, R.; Ghafourian, H.; Asef, Y.; Davarpanah, S.; Sepehr, S. Removal and recovery of lead using nonliving biomass of marine algae. J. Hazard. Mater. 2002, 92, 253-262. [CrossRef]

21. Iqbal, M.; Edyvean, R. Biosorption of lead, copper and zinc ions on loofa sponge immobilized biomass of Phanerochaete chrysosporium. Miner. Eng. 2004, 17, 217-223. [CrossRef]

22. Sekhar, K.C.; Kamala, C.T.; Chary, N.S.; Sastry, A.R.K.; Rao, T.N.; Vairamani, M. Removal of lead from aqueous solutions using an immobilized biomaterial derived from a plant biomass. J. Hazard. Mater. 2004, 108, 111-117.

23. Agency for Toxic Substances and Disease Registry. Public Health Service. Toxicological Profile for Lead; U.S. Department of Health and Human Services, Agency for Toxic Substances and Disease Registry (ATSDR): Atlanta, GA, USA, 2007.

24. Järup, L. Hazards of heavy metal contamination. Brit. Med. Bull. 2003, 68, 167-182. [CrossRef] [PubMed] 
25. Ge, F.; Li, M.-M.; Ye, H.; Zhao, B.-X. Effective removal of heavy metal ions $\mathrm{Cd}^{2+}, \mathrm{Zn}^{2+}, \mathrm{Pb}^{2+}$ and $\mathrm{Cu}^{2+}$ from aqueous solution by polymer-modified magnetic nanoparticles. J. Hazard. Mater. 2012, 211-212, 366-372. [CrossRef]

26. Lasheen, M.R.; El-Sherif, I.Y.; Sabry, D.Y.; El-Wakeel, S.T.; El-Shahat, M.F. Removal and recovery of Cr (VI) by magnetite nanoparticles. Desalin. Water Treat. 2014, 52,1-13. [CrossRef]

27. Covaliu, C.I.; Păun, I.; Vasile, E. New application of magnetite nanomaterial for a cationic surfactant removal from wastewater. Rev. Rom. Mater. 2020, 50, 301-306.

28. Rajput, S.; Pittman, C.U., Jr.; Mohan, D. Magnetic magnetite $\left(\mathrm{Fe}_{3} \mathrm{O}_{4}\right)$ nanoparticle synthesis and applications for lead $\left(\mathrm{Pb}^{2+}\right)$ and chromium $\left(\mathrm{Cr}^{6+}\right)$ removal from water. J. Colloid Interface Sci. 2016, 468, 334-346. [CrossRef]

29. Nassar, N.N. Rapid removal and recovery of $\mathrm{Pb}$ (II) from wastewater by magnetic nanoadsorbents. J. Hazard. Mater. 2010, 184, 538-546. [CrossRef]

30. Hoang, V.T.; Lam, D.T.; Thinh, N.N. Preparation of chitosan/magnetite composite beads and their application for removal of Pb (II) and Ni (II) from aqueous solution. Mat. Sci. Eng. C 2010, 30, 304-310.

31. Madhu, K.; Pittman, U.C., Jr.; Mohan, D. Heavy metals [chromium (VI) and lead (II)] removal from water using mesoporous magnetite $\left(\mathrm{Fe}_{3} \mathrm{O}_{4}\right)$ nanospheres. J. Colloid Interface Sci. 2015, 442, 120-132.

32. Abu, Z.M.B.; Zayed, B.Z.S.; Tay, W.J.D.; Kus, H. Mohammad Shahab Uddin, $\mathrm{Fe}_{3} \mathrm{O}_{4}$ / cyclodextrin polymer nanocomposites for selective heavy metals removal from industrial wastewater. Carbohyd. Polym. 2013, 91, 322-332.

33. Aya, S.M.; Nadia, A.Y.; Ahmed, O.A.; El, N.; Selim, M.M. Removal of lead ions from industrial wastewater using magnetite loaded on silica support. Egypt. J. Chem. 2019, 62, 2163-2173.

34. Jianming, Z.; Shangru, Z.; Shi, L.; Zuoyi, X.; Yu, S.; Qingda, A.; Ge, T. Pb(II) removal of $\mathrm{Fe}_{3} \mathrm{O}_{4} @ \mathrm{SiO}_{2}-\mathrm{NH}_{2}$ core-shell nanomaterials prepared via a controllable sol-gel process. Chem. Eng. J 2013, 215-216, 461-471.

35. Abdus, S.N.; Adekola, F.A. The influence of $\mathrm{pH}$ and adsorbent concentration on adsorption of lead and zinc on a natural Goethite. Afr. J. Environ. Sci. Technol. 2005, 6, 55-66.

36. Akinbiyi, A. Removal of Lead from Aqueous Solutions by Adsorption Using Peat Moss. Master's Thesis, University of Regina, Regina, SK, Canada, 2000; pp. 1-116.

37. Parvathi, K. Lead biosorption onto waste beer yeast by product, a means to decontaminate effluents generated from battery manufacturing industry. Electron. J. Biotechnol. 2007, 10, 1-4. [CrossRef]

38. Sridevi, V.; Chandana Lakshmi, M.V.V.; Satyavani, V. Adsorption isotherm studies of lead from aqueous solutions using fly. Int. J. Innov. Res. Sci. Eng. Technol. 2013, 2, 7021-7030.

39. Krishnan, K.A.; Sheela, A.; Anirudhan, T.S. Kinetic and equilibrium modeling of liquid phase adsorption of Pb II Chelates on activated carbons. J. Chem. Technol. Biotechnol. 2003, 78, 642-653. [CrossRef]

40. Lalhruaitluanga, H.; Jayaram, K.; Prasad, M.N.V.; Kumar, K.K. Pb (II) adsorption from aqueous solutions by raw and activated charcoals of Melocanna baccifera Roxburgh (Bamboo)—A comparative study. J. Hazard. Mater. 2010, 175, 311-318. [CrossRef] [PubMed]

41. Anwar, J.; Umer, S.; Waheed-uz-Zaman, S.M.; Dar, A.; Anwar, S. Removal of Pb (II) and Cd (II) from water by adsorption on peels of banana. Bioresour. Technol. 2010, 101, 1752-1755. [CrossRef]

42. Sekar, M.; Sakthi, V.; Rengaraj, S. Kinetics and equilibrium adsorption study of Pb (II) onto activated carbon prepared from coconut shell. J. Colloid Interface Sci. 2004, 279, 307-313. [CrossRef] [PubMed]

43. Lugo-Lugo, V.; Hernandez-Lopez, S.; Barrera-Diaz, C.; Urena-Nunez, F.; Bilyeu, B. A comparative study of natural, formaldehydetreated and copolymer-grated orange peel for $\mathrm{Pb}$ (II) adsorption under batch and continuous mode. J. Hazard. Mater. 2009, 161, 1255-1264. [CrossRef] [PubMed]

44. Qaiser, S.; Saleemi, A.R.; Ahmad, M.M. Heavy metal uptake by agro based waste materials. Electron. J. Biotechnol. 2007, 10, 1-12. [CrossRef]

45. Naiya, T.K.; Bhattacharya, A.K.; Das, S.K. Adsorption of Pb (II) by sawdust and neem bark from aqueous solutions. Environ. Prog. 2008, 27, 313-328. [CrossRef]

46. Roonasi, P.; Holmgren, A. An ATR-FTIR study of sulphate sorption on magnetite; rate of adsorption, surface speciation, and effect of calcium ions. J. Colloid Interface Sci. 2009, 333, 27-32. [CrossRef]

47. Johnson, S.B.; Franks, G.V.; Scales, P.J.; Boger, D.V.; Healy, T.W. Surface chemistry-rheology relationships in concentrated mineral suspensions. Int. J. Miner. Process. 2000, 58, 267-304. [CrossRef]

48. Simeonidis, K.; Mourdikoudis, S.; Moulla, M.; Tsiaoussis, I.; Martinez-Boubeta, C.; Angelakeris, M.; Dendrinou-Samara, C.; Kalogirou, O. Controlled synthesis and phase characterization of Fe-based nanoparticles obtained by thermal decomposition. J. Magn. Magn. Mater. 2007, 316, e1-e4. [CrossRef]

49. Ahmed, M.A.; Ali, S.M.; El-Dek, S.I.; Galal, A. Magnetite-hematite nanoparticles prepared by green methods for heavy metal ions removal from water. Mater. Sci. Eng. B 2013, 178, 744. [CrossRef] 